\title{
POLYNEMUS PARADISEUS.
}

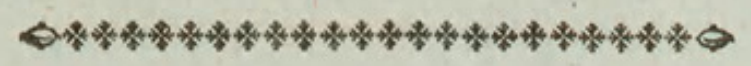

CHARACTER GENERICUS.

Radii filiformes liberi jugulares.

$$
\begin{aligned}
& \text { Bloch. ichth. } 12 . \text { p. } 15 . \\
& \text { pisces abdominales. }
\end{aligned}
$$

CHARACTER SPECIFICUS, छ́c.

POLYNEMUS radiis liberis septem jugularibus, pinna caudæ bifurca.

Bloch. ichth. 12, p. 20.

POLYNEMUS digitis septem, cauda bifida.

$$
\text { Lin. Syst. Nat. p. } 522 .
$$

Piscis Paradisaa.

Edw. t. 208.

Maria Americana incolit Polynemus paradiseus, magnitudine dimidiata in tabula depictus. 



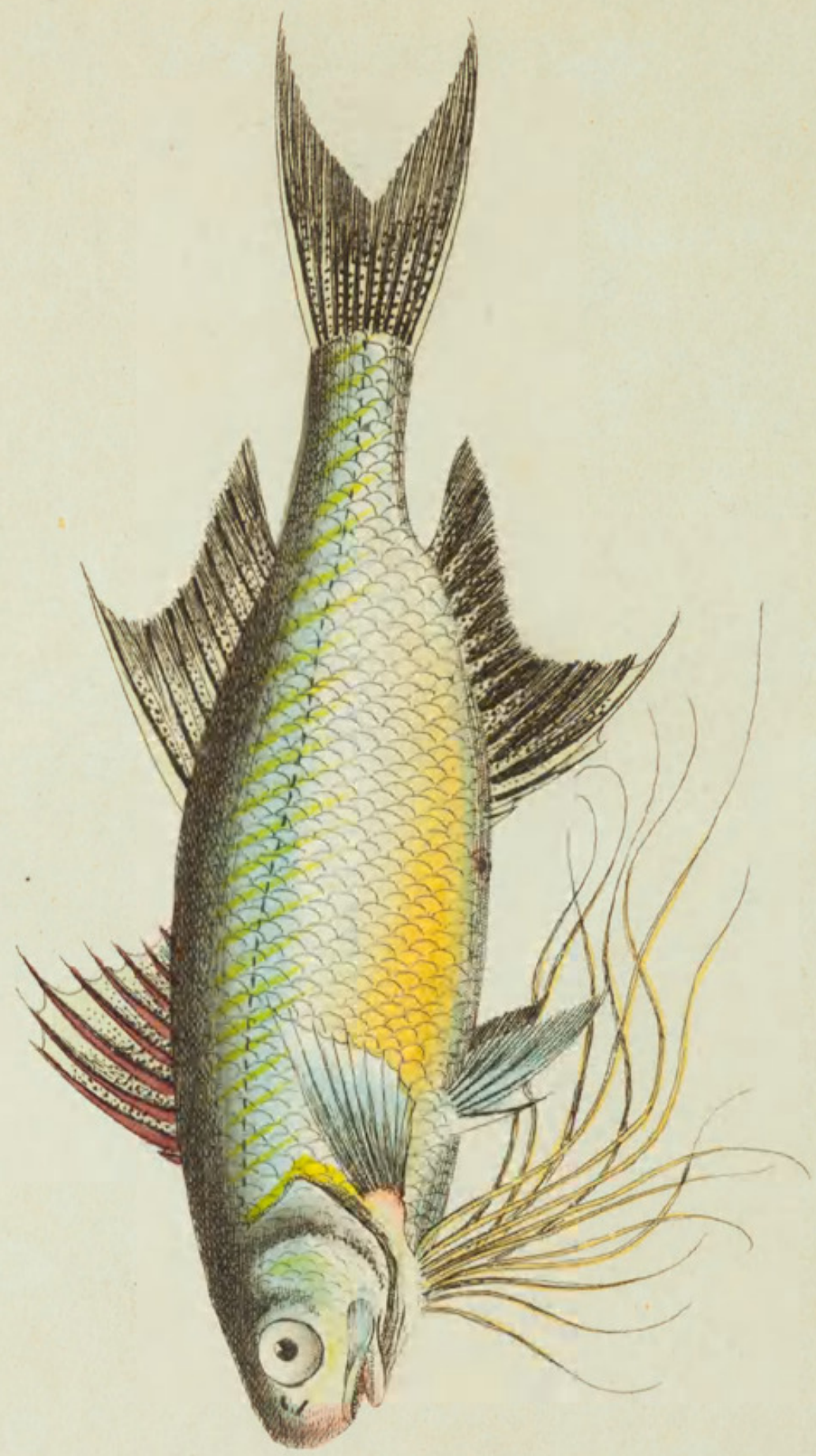

ถ 


\section{PARADISE POLYNEMUS.}

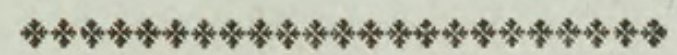

GENERIC CHARACTER.

Loose radii or filaments proceeding from each side of the throat.

SPECIFIC CHARACTER, छ้c.

POLYNEMUS with seven loose filaments on each side the throat, and forked tail.

The Paradise-Fish.

Der Paradies-fisch.

Bloch.pl. 402.

The Mango-Fish.

Edw. pl. 208.

Le Poisson de Paradis.

Bonaterre encycl. ichth. p. 182.

This fish is a native of the American seas, and is represented on the plate of about half its natural size. 


\section{$2 \mathrm{BHL}$ Biodiversity Heritage Library}

Shaw, George. 1801. "The Paradise Polynemus, Polynemus paradiseus [PI. 470]." The Naturalist's Miscellany 12(CXL), https://doi.org/10.5962/p.310916.

View This Item Online: https://www.biodiversitylibrary.org/item/278722

DOI: https://doi.org/10.5962/p.310916

Permalink: https://www.biodiversitylibrary.org/partpdf/310916

\section{Holding Institution}

Museums Victoria

\section{Sponsored by}

Atlas of Living Australia

\section{Copyright \& Reuse}

Copyright Status: Public domain. The BHL considers that this work is no longer under copyright protection.

This document was created from content at the Biodiversity Heritage Library, the world's largest open access digital library for biodiversity literature and archives. Visit BHL at https://www.biodiversitylibrary.org. 